\title{
Effect of Mercury concentration on $P$. putida growth in Mercury removal
}

\author{
Abdul Aziz Bin Mohd Azoddein ${ }^{1 *}$, Rosli Bin Mohd Yunus ${ }^{2}$, Nik Meriam Bt Nik Sulaiman ${ }^{3}$, \\ Ahmad Bazli Bin Bustary ${ }^{4}$, Faten Ahada Bt Mohd Azli ${ }^{5}$, Suzana Bt Che Sayuti ${ }^{6}$
}

\author{
1, 2, 3, 4, 5, 6 Universiti Malaysia Pahang, Gambang, Malaysia
}

\author{
Index Terms \\ Pseudomonas Putida \\ Mercury Removal \\ Bacteria Growth \\ Bioreactor
}

Received: 20 June 2016

Accepted: 2 February 2017

Published: 16 October 2017

\begin{abstract}
Mercury is a toxic pollutant emitted from industrial sectors to the environment and distributed globally. In the current research the potential for biological treatment of industrial wastewater contaminated with mercury was evaluated using Pseudomonas putida (P. putida) under various conditions in a bioreactor. The effect of mercury concentration on the P. putida growth of bacteria and also mercury removal was determined. Modifications in optimum operating conditions in shake flask and bioreactor need to be determined so it could bring us to a better result. In this research, optimum conditions for the growth of P. putida in shake flask are identified: acclimatization time 24 hours, orbital shaker speed $180 \mathrm{rpm}$, temperature $37^{\circ} \mathrm{C}, \mathrm{pH} 7$, and nutrient concentration $8 \mathrm{~g} / \mathrm{L}$. The removal efficiency obtained is $99 \%$ for $1 \mathrm{ppb}$, $99.8 \%$ for $6 \mathrm{ppb}$, and $98.6 \%$ for $19 \mathrm{ppb}$ while for $1000 \mathrm{ppb}$ mercury, the removal efficiency is $92 \%$ for 1 hour and $98 \%$ for 28 hours. In $2 \mathrm{~L}$ bioreactor, the same condition as shake flask is applied with an agitator speed of $180 \mathrm{rpm}$ and aeration time of $0.50 \mathrm{vvm}$. For $1300 \mathrm{ppb}$ and $3000 \mathrm{ppb}$, the removal efficiency is $89 \%$ and $94 \%$, respectively. The findings of this study can be used as a reference for future application in the industrial wastewater treatment plant. .
\end{abstract}

\section{INTRODUCTION}

Mercury (Hg) is one of the most toxic elements found on earth. It can deactivate vital cell functions when it binds with the sulfhydryl groups of enzymes and proteins. The sediments of mercury that enter the environment can remain for decades. When it enters the aquatic system, a form of toxic methylmercury is taken up and is subsequently biomagnified through the food chain. It will threaten the health of top predators, such as birds, fish, seals, and man Braune et al. [1] and Muir et al. [2]. High concentration of mercury vapour can cause acute necrotizing bronchitis and pneumonitis which could lead to death from respiratory failure. Meanwhile, long-term exposure can bring effect to the central nervous system. Mercury also accumulates in kidney tissues, directly causing renal toxicity, including proteinuria or nephritic syndrome [3]. High concentration of $\mathrm{Hg}^{2+}$ causes impairment of pulmonary function and kidney, chest pain, and dyspnoea [4].

Mercury is one of the heavy metals of concern, found in wastewaters coming from oil refinery, chloralkali manufacturing industry, paint, pharmaceutical, paper, and battery manufacturing industries. Mercury and mercurial compounds are highly toxic contaminants in the aquatic systems and soils. They are dangerous pollutants because they can disperse widely into environment due to their high mobility and potentially dangerous concentration throughout the food chain $[5,6]$. Mercury in crude oil or gas affects quality and price of saleable products and raises equipment integrity concerns in proportion to concentration that may be present. After a certain limit, mercury also could make some problems to refinery operations because this mercury would deactivate catalysts and consequently lower the quality of refined products.

\footnotetext{
*Corresponding author: Abdul Aziz Bin Mohd Azoddein

†Email: aaziz@ump.edu.my
} 
Various technologies are found valid for removing mercury from water and wastewater like reverse osmosis, chemical precipitation, and conventional coagulation. Other than that, ultrafiltration, magnetic filtration, ion exchange, activated carbon adsorption, and chemical reduction are also used in treating mercury $[7,8]$. Physicochemical technologies are expensive and not environmentfriendly. According to Zeroul [9] and Malakahmad [10] biological is one method that can be adopted for the removal of toxic heavy metals such as mercury from petroleum-based industries' wastewater. Biological technologies have the advantages for removal of pollutants as it can be accomplished in-situ at the contaminated site. It is also environmentally benign where no secondary pollution is produced and they are cost effective [11]. In fact, it is indicated that bacteria, fungi, yeasts, and algae can reduce heavy metals from aqueous solution by adsorption [12].

The stringent legislation of wastewater discharge quality by Malaysia also is in need of expensive and effective treatment method of wastewater in order to fulfil the discharge limit requirement by the Department of Environment $[13,14]$. Minimum allowable concentration of mercury is below or equivalent to $5 \mathrm{ppb}$ for Standard A and $50 \mathrm{ppb}$ for Standard B. As these problems arise, various effective methods are to be developed. In the recent years, application of biotechnology in controlling and removing mercury pollution has gained much attention, gradually becoming a popular issue in the field of heavy metals pollution control because it is a highly potential method application in wastewater treatment plant especially in petroleum-based industries that face a lot of mercury contamination in the processing systems [15]. Biological technology that was originated by Nakamura [16] by using P. putida in treatment of mercury contaminated wastewater in Minamata Bay seems to have great potential. However, even much has been discussed in literatures regarding the potential usage of $P$. putida in treating mercury-contaminated wastewater, no specific strains were mentioned. Hence, there is a need to conduct research on a chosen P. putida strain to understand its behaviour in treating mercury-contaminated wastewater under various conditions. Other than that, membrane bioreactor is also reliable, easier, adaptable, and flexible for wastewater application $[17,18,19]$.

The objectives of this study are to determine the effect of mercury concentration on the growth of $P$. putida bacteria in wastewater. It is important to understand the optimum condition for the bacteria growth. Different con- centrations of mercury were used as manipulated variable and the trend of growth was observed. The optimum concentration of mercury was observed and the mercury removal percentage also can be obtained from this study.

\section{LITERATURE REVIEW}

Mercury in the air would settle into water bodies and affect aquatic environment $[20,21]$. This airborne mercury can fall to the ground in raindrops, in dust, or simply due to gravity (known as "air deposition"). Mercury density is higher than $5 \mathrm{~g} / \mathrm{cm}^{3}$ [22]. After the mercury falls, it can end up in streams, lakes, or estuaries as inorganic mercury, where it can be transferred to organic mercury (methylmercury) through microbial activity. Mercury is a persistent, mobile, and bioaccumulative element in the environment and retained in organisms. Most of the mercury found in the environment is inorganic since mercury is never broken down into other chemical and harmless form. Once mercury enters into the environment, mercury permanently exists in the environment by changing its chemical forms depending on the environment $[23,24]$.

Mercury is a trace component of all fossil fuels including natural gas, gas condensates, crude oil, coal, tar sands, and other bitumen. The use of fossil hydrocarbons as fuels provides the main opportunity for emissions of the mercury they contain to the atmospheric environment but other avenues also exist in production, transportation, and in processing systems [25]. These other avenues may provide mercury directly to air, water or solid waste streams. In addition, the distribution and transformation of mercury in production, transportation, and processing are considered relative to the determination of mercury in air emissions, wastewater, and products from oil and gas processing facilities [26].

In Minamata Bay, mercury-resistant Pseudomonas spp. were isolated from sediments near the drainage outlet to the Bay. Pseudomonas spp. dominated the bacteria with the highest resistance to mercury [27]. The mercuryresistant Pseudomonas strains were more resistant to inorganic mercury, methylmercury, and phenylmercury [16]. Previous studies showed that mercury causes an increased relative abundance of mercury-resistant bacteria isolates rarely been carried out Moreover, studies showed mercury did not affect the number of culturable Pseudomonas spp. even though the number of bacteria growing on general medium was affected [28]. 
P. putida was isolated from a polluted creek in Urbana, IL by enrichment of culture with ethylbenzene as the sole source of carbon and energy. P. putida is one of the most well-studied aromatic hydrocarbon degrading bacterial strains. Well over 200 articles have been written about various aspects of $P$. putida physiology, enzymology, and genetics by microbiologists and biochemists, in addition to more applied studies by chemists and environmental engineers utilizing $P$. putida and its enzymes for green chemistry applications and bioremediation [27].

\section{MATERIALS AND METHODS}

\section{A. Microorganism}

The P. putida bacteria used were obtained from Merck (Malaysia) Sdn. Bhd as the dealer of P. putida (freeze dried) from Microbiologics, 217 Osseo Ave. North, St. Cloud, USA. There are $5 \%$ of pepton meat and $3 \%$ meat extract in the $P$. putida nutrient. The growth medium for P. putida was prepared by suspending $8 \mathrm{~g}$ nutrient powder in $1 \mathrm{~L}$ of De-Ionized (DI) water. The growth media were sterilized in an autoclave at a temperature of $121^{\circ} \mathrm{C}$ and a pressure of 15 psi for 25 minutes. The culture was kept below $5^{\circ} \mathrm{C}$ and this culture stock was used for all subsequent works.

\section{B. Chemicals}

Analytical grade of ethanol, peptone, yeast extract, $\mathrm{KH}_{2} \mathrm{PO}_{4}, \mathrm{MgSO}_{4} \cdot 7 \mathrm{H}_{2} \mathrm{O}$, Urea, $\mathrm{NaCl}, \mathrm{HNO}_{3}, \mathrm{HCl}$, and $\mathrm{NaOH}$, were purchased from Merck (Malaysia) Sdn. Bhd. Stannous Chloride solution $\left(\mathrm{SnCl}_{2}\right), \mathrm{Hg}\left(\mathrm{NO}_{3}\right)_{2}$ as mercury standard solution (1000 ppm), and $\mathrm{H}_{2} \mathrm{SO}_{4}$ were obtained from Orbiting Scientific \& Technology Sdn. Bhd. Ethanol was used as cleaning solvent. Distilled water was used to prepare the culture medium, washing glassware, cleaning, and as cooling water. DI water was used for analytical purposes such as in UV spectrophotometer, mercury analyser, and also for the preparation of chemical standard solution to determine standard calibration curve, and for sample dilution.

\section{Process of Culturing P. putida from Freeze-Dried}

Culturing method was used and appropriate biosafety protocol of cultures was adopted in this experiment. Steps should be taken as follows: preparing the culture in biological safety cabinet, wearing of suitable eye protection, holding vials away from face, wearing of gloves, ISSN: 2414-3103 and sterilizing all empty vials and fragments before disposal.

Sharp blade was used to remove the packing skin of culture or it needs to be soaked for a few minutes while the ampule briskly scored once with a sharp file about one inch from the tip. The ampule was disinfected with alcoholdampened gauze and the gauze was wrapped around the ampule to break the scored area. It is needed to ensure that the gauze is not too wet so that alcohol is not being sucked into the ampule when scored area is broken. Sterile forceps were used to remove the cotton. The suspension was then transferred to an oven heated to $30^{\circ} \mathrm{C}$ to let the culture incubate for 24 hours after the culture was properly mixed in $0.50 \mathrm{ml}$ nutrient broth. A few drops of this suspension were then transferred to slanting agar, nutrient broth, and plate agar to start the growth of the culture [29].

\section{Stock Culture}

The purity of stock culture is important so that it can be used for a long time. The nutrient is preserved and broth can only last for a few weeks and after that, the culture will start to decay due to nutrient depletion and accumulation of toxic by-product. A stock culture can be stored in a refrigerator up to six months [30]. Sterility of the media must be maintained during transfer of a pure culture, P. putida.

Firstly, inoculating loop is sterilized using a flame from a Bunsen burner until it is red hot. The loop is cooled down before dipping into the broth culture. In order to disperse the cells, the tube containing pure culture is shaken. The cap of test tube is removed and the lip is sterilized using the Bunsen burner flame. Then the tube is slanted and the loop is inserted into the culture broth. Next, the culture tube is capped after being sterilized. The tube is put aside and another test tube with Nutrient Agar (NA) is sterilized with flame. The inoculating loop that contains a smear of culture is inserted into the second test tube while gently sliding the loop in a continuous streaking motion on the surface of the agar. The loop is again flamed after using it. The test tube containing the pure culture on NA is then incubated at $30^{\circ} \mathrm{C}$ for 24 hours. It is then kept in a refrigerator to be used as stock culture.

\section{E. Experiment Shake Flask}

All the glassware must be sterilized before the ex-

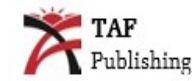


periment can be run. All petri dishes, pipettes, test tubes, and Erlenmeyer flasks are placed in metal can and will be autoclaved at temperature $121^{\circ} \mathrm{C}$ and pressure at $15 \mathrm{psi}$ for 25 minutes. After sterilization cycle is over, autoclave is allowed to cool for 15 minutes before it can be opened. Glassware is stored in another sterile container until required for use. Medium that has been fermented in shake flask is also sterilized with standard procedure of autoclave sterilization [31].

Bacteria Inoculum was prepared by taking a loop-full of $P$. putida colony from a culture that has been cultivated on Nutrient Agar (NA). The culture is then transferred into $10 \mathrm{ml}$ of Nutrient Broth (NB) which is $10 \%$ of the medium volume or with the ratio of 1:9, and is then incubated at $30^{\circ} \mathrm{C}$ for 24 hours as proposed by the manufacturer (Merck (Malaysia) Sdn. Bhd.). After 24 hours, the colony is transferred to a $25 \mathrm{ml}$ inoculum flask containing $90 \mathrm{ml}$ nutrient broth. The cells are grown at $37^{\circ} \mathrm{C}$ while being shaken at $180 \mathrm{rpm}$. Then, the samples are analysed using UV spectrophotometer at Optical Density (OD) of $600 \mathrm{~nm}$ to monitor the growth of P. putida [32].

The study on acclimatization time, orbital shaker speed, temperature, substrate concentration $\mathrm{pH}$, and mercury concentration was varied in order to get the best conditions for the bacteria growth. A series of experiments using different concentrations of $\mathrm{Hg}$ was conducted to study the effect of $\mathrm{Hg}$ on growth of P. putida. There were four samples prepared: Sample A-P. putida in nutrient broth NB were mixed with fresh NB $(8 \mathrm{~g} / \mathrm{L})$; Sample B-P. putida in NB were grown in NB with $6.00 \mathrm{ppb}$ Hg solution; Sample C-P. putida in NB were grown in NB with 1.00 ppb Hg solution while Sample D-P. putida in NB were grown in NB with $19.00 \mathrm{ppb}$ Hg solution.

\section{Bioreactor}

2L batch mode bioreactor with closed-system was used in this study where the sterile nutrient solution was inoculated with P. putida under optimum operating conditions obtained from earlier shake flask experiment. Experiment was conducted for 51 hours with operating conditions of 24 hours acclimatization, temperature at $37^{\circ} \mathrm{C}, \mathrm{pH} 7$, and nutrient concentration of $8 \mathrm{~g} / \mathrm{L}$. In this case, propeller speed, aeration rate, and mercury concentration were varied to investigate the most suitable condition for the bacteria to grow. Then the growth of $P$. putida was observed by using UV spectrophotometer.

\section{F. Determination of P. putida Growth}

P. putida and method is based on the absorption of light by suspended cells in media of the sample culture. Intensity of the transmitted light was measured using a spectrophotometer. Sampling method was done by detaching the shake flask from orbital shaker and $5 \mathrm{ml}$ of liquid sample was taken for every hour to be analysed until decay phase was observed at all concentrations. The growth of $P$. putida was monitored at $600 \mathrm{~nm}$ absorbance.

\section{G. Mercury Determination}

Mercury content in liquid samples or in solid samples can be determined by using mercury analyser system, RA-3000 Nippon Instrument Corporation (NIC) Japan. It is using reducing vaporization with cold vapour atomic absorption spectrometry. Mercury compounds in the sample were first pre-treated with strong acid and an oxidizing agent to change the compound into divalent mercury ions $\left(\mathrm{Hg}^{2+}\right)$. Samples need to be diluted if the mercury content in the sample is in high concentration because the analyser only can measure up to $15 \mathrm{ppb}$. Solutions that had been measured were added into the sample and then the test tube was plugged into the socket of Mercury Analyser test tube. The software for the mercury analyser was run for 3 minutes before the result could be obtained.

\section{RESULTS AND DISCUSSION}

\section{A. Effect of Low Mercury Concentration on P. putida Growth}

Table 1 shows the effect of low mercury concentration (ppb) on P. putida growth behaviour. Table 1 consists of several parameters such as initial $\mathrm{Hg}$ concentration, OD, biomass concentration, final $\mathrm{Hg}$ concentration, $\mathrm{Hg}$ removal percentage, and ratio of mercury mass over cell mass. In determining the Hg removal percentage, the following equation 1 was being applied:

Percentage of Hg Removal $=\frac{A-B}{A} \times 100 \%$

Where,

-A is initial Hg Concentration (ppb)

-B is final Hg Concentration (ppb) 
TABLE 1

EFFECT OF LOW MERCURY CONCENTRATION (ppb) ON P. PUTIDA GROWTH BEHAVIOUR FOR 24 HOURS

\begin{tabular}{lccccccc}
\hline \hline $\begin{array}{l}\text { Initial Hg } \\
\begin{array}{l}\text { Concentration, } \\
\text { (ug/L) }\end{array}\end{array}$ & $\begin{array}{c}\mathrm{OD}_{0} \\
\text { Initial }\end{array}$ & $\begin{array}{c}\mathrm{OD}_{\max } \\
(4 \mathrm{hr})\end{array}$ & $\begin{array}{c}\mathrm{OD} \\
(24 \mathrm{hr})\end{array}$ & $\begin{array}{c}\text { Biomass } \\
\text { Concentration, } \\
\mathrm{g} / \mathrm{L})\end{array}$ & $\begin{array}{c}\text { Final Hg } \\
\text { Concentration, } \\
\text { (ug/L) }\end{array}$ & $\begin{array}{c}\mathrm{Hg} \% \\
\text { Removal }\end{array}$ & Ug Hg/gcell \\
\hline 0.00 & 0.00 & 0.53 & 0.39 & 0.02 & 0.00 & 0.00 & 0.00 \\
1.00 & 0.00 & 0.50 & 0.08 & 0.03 & 0.01 & 99.00 & 0.33 \\
6.00 & 0.00 & 0.37 & 0.03 & 0.01 & 0.01 & 99.00 & 1.00 \\
19.00 & 0.00 & 0.30 & 0.12 & 0.04 & 0.27 & 98.50 & 6.75 \\
\hline \hline
\end{tabular}

Based on Table 1, it can be seen that the OD decreased from 0.53 after 4 hours to 0.39 after 24 hours for the control sample with no mercury added. This shows the normal behaviour of $P$. putida growth in batch system when the nutrient is introduced only at an early stage. Cell density may increase for the first 4 hours, after which it starts to reduce due to the decreasing of nutrient concentration and from the study conducted earlier, it was shown the growth rate of $P$. putida is dependent on nutrient concentration. Growth termination can be caused by exhaustion of essential nutrients or accumulation of toxic by-products. When there is accumulation or inhibitory product at the medium, the growth rate will slow depending on inhibitor production at a certain level of inhibitor concentration [33].

For culture with mercury concentration of $1 \mathrm{ppb}$ and after 4 hours of experiment, the maximum optical density, $\mathrm{OD}_{\max }$ was 0.50 . Also, the cell density was further decreased to 0.08 after 24 hours. As a result, the mercury concentration decreased from $1 \mathrm{ppb}$ to $0.01 \mathrm{ppb}$ and the percentage mercury removal was $99 \%$ and the ratio of mercury mass over cell mass was $1 \mu \mathrm{g} \mathrm{Hg}$ /gcell. For concentration of 6.00 ppb, the maximum optical density, ODmax obtained was 0.37 and the cell density decreased to 0.03 after 24 hours of experiment. It can be seen that mercury concentration decreased from $6 \mathrm{ppb}$ to $0.01 \mathrm{ppb}$ with percentage mercury removal of $99.58 \%$. In this case, the ratio of mercury mass over cell mass was $0.33 \mu \mathrm{g} \mathrm{Hg} /$ gcell. Finally, culturing with $19 \mathrm{ppb}$ mercury concentration, the results showed that the maximum optical density, $\mathrm{OD}_{\max }$ was 0.30 . After 24 hours, the optical density was reduced to 0.12 . The percentage of mercury removal was $98.5 \%$ which is just slightly lower than two experiments carried out earlier. As a result, ratio of mercury mass over cell mass increased dramatically which was $6.75 \mu \mathrm{g} \mathrm{Hg} / \mathrm{gcell}$.

Since full mercury retention at low concentration was obtained from a 24-hour inoculation, it may be concluded that the microbial community was present and the activity of detoxification occurred. The mercury detoxification mechanism is according to the unique peculiarities of this metal: the electrochemical potential of $\mathrm{Hg}^{2+} / \mathrm{Hg}^{0}$ at $\mathrm{pH} 7$ is $+430 \mathrm{mV}$. This means living cells have abilities to reduce $\mathrm{Hg}^{2+}$ to elemental form $\mathrm{Hg}^{0}$ that is non-toxic to human and also microorganism [34]. Although micro-organisms cannot destroy metals but they can make changes in their chemical properties via a surprising array of mechanisms that can be applied to treat toxic metal contamination involving highly specific biochemical pathways that have evolved for their protection [35].

Ratio of sorptive surface area to the total metal ions available is high at very low concentrations of metal ions Mortazavi [23]. So, chances for metal removal are much greater. When mercury concentration is increased, binding sites become more quickly saturated when the amount of biomass concentration remains constant. The discharge limit for mercury for industrial wastewater is $50 \mathrm{ppb}$ for Standard B as DOE as required by Environmental Quality Act (EQA) [36]. However, some local water authorities at some other countries demanded the limit to be $10 \mathrm{ppb}$. This is of crucial importance for a potential industrial application of the microbial mercury remediation technology.

\section{B. Mercury Removal by P. putida in Orbital Shaker at Optimum Operating Conditions}

Mercury removal was conducted at optimum operating conditions and when the growth of $P$. putida is higher. The experiments were conducted for 28 hours, employing the yield of optimum operating conditions in a shake flask with 24-hour acclimatization, orbital shaker speed $180 \mathrm{rpm}$, temperature $37^{\circ} \mathrm{C}, \mathrm{pH} 7$, and nutrient concentration $8 \mathrm{~g} / \mathrm{L}$. The results of the growth of $P$. putida and the corresponding mercury removal for 1000 ppb mercury concentration are shown in Table 2. The parameters related to the growth of $P$. putida and mercury removal are 
summarized in Table 3. Based on the results, the specific growth rate, $\mu$ is $0.70 \mathrm{hr}^{-1}$. This result is lower than the spe- cific growth rate obtained from the earlier experiment at optimum conditions without mercury in the sample.

TABLE 2

THE GROWTH KINETICS OF P. PUTIDA IN MERCURY REMOVAL AT 1000 ppb CONCENTRATION

\begin{tabular}{lccccc}
\hline \hline Time (hr) & Optical Density (OD) & Biomass Concentration (g/L) & Hg Concentration (ug/L) & ugHg/gcell & \% Hg Removal \\
\hline 0.00 & 0.00 & 0.00 & 1000.00 & 0.00 & 0.00 \\
1.00 & 0.17 & 0.06 & 79.00 & 1215.00 & 92.10 \\
2.00 & 0.63 & 0.24 & 56.00 & 230.00 & 94.40 \\
3.00 & 0.86 & 0.33 & 43.00 & 130.00 & 95.70 \\
20.00 & 0.58 & 0.22 & 34.00 & 153.00 & 96.60 \\
23.00 & 0.51 & 0.20 & 24.00 & 121.00 & 97.60 \\
28.00 & 0.50 & 0.19 & 20.00 & 105.00 & 98.00 \\
\hline \hline
\end{tabular}

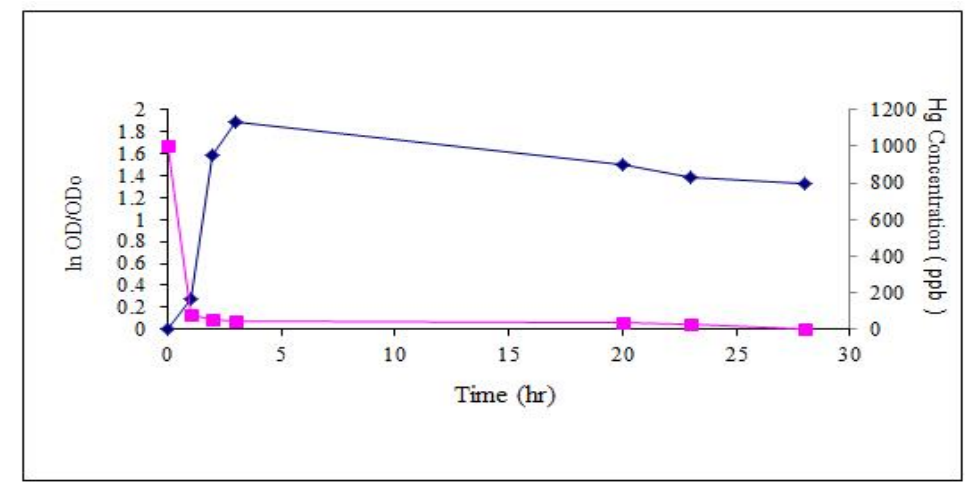

Fig. 1. Mercury (1000 ppb) removal by P. Putida in shake flask at optimum conditions

TABLE 3

MERCURY (1000 ppb) REMOVAL BY P. PUTIDA IN ORBITAL SHAKER AT OPTIMUM OPERATING CONDITIONS

\begin{tabular}{lcc}
\hline \hline Growth Parameter & Min & Max \\
\hline Specific growth rate, $\mu\left(\mathrm{hr}^{-1}\right)$ & 0.70 & - \\
OD & 0.13 & 0.86 \\
ln OD/OD 0 & 0.27 & 1.89 \\
Number of generation, $n$ & 0.39 & 1.98 \\
Generation time, $g$ (hr) & 0.88 & 14.64 \\
Growth rate constant, $k(\mathrm{hr}-1)$ & 0.06 & 0.78 \\
Hg removal $(\%)$ & - & 98.00 \\
\hline \hline
\end{tabular}

Green-Ruiz [37] has showed that the maximum achievable percentage of mercury removal at $1000 \mathrm{ppb}$ concentration by Basillus $s p$ is $88 \%$. However, the percentage of mercury removal achieved in this experiment is better at $92.1 \%$ for the first hour and $98 \%$ after 28 hours. Also, the cell density decreased to 0.49 compared to the maximum cell density, but cell density of 0.86 was detected after 3 hours of experiment in the study conducted by Mortazavi
[23]. This is because with the increase in cell concentration, the percentage removal increases as the number of possible binding sites is increased.

At low concentration of metal ions, the ratio of sorptive surface area to total available metal ions available is high. Thus, there is a greater chance for highly toxic watersoluble ionic mercury been taken up by P. Putida and reduced to insoluble metallic mercury through intracellular 
enzyme mercuric reductase, encoded by merA gene [20]. Metallic mercury subsequently diffuses out of cells. The reduction process can be continuously performed within a submersed microbial and resulting in accumulation of metallic mercury within bioreactor.

\section{Effect of Mercury Concentration on Growth of P. putida in Bioreactor}

Mercury concentration in model wastewater was prepared at $1300 \mathrm{ppb}$ and $3000 \mathrm{ppb}$. The effect of $P$. putida on mercury at $1300 \mathrm{ppb}$ was investigated for more than 48 hours at optimum operating conditions with 24-hour acclimatization time, at $30^{\circ} \mathrm{C}$ in incubator oven, agitator speed of $180 \mathrm{rpm}$, temperature of $37^{\circ} \mathrm{C}, \mathrm{pH} 7$, nutrient concentration of $8 \mathrm{~g} / \mathrm{L}$, and aeration of $0.50 \mathrm{vvm}$ for 14 hours. Results of parameters related to $P$. putida growth behaviour are presented in Table 4 and a plot of $P$. putida growth and mercury removal is presented in Figure 2. In the lag phase, it can be seen that $P$. putida immediately grew after inoculation. It is also noted that mercury is reduced dramatically $(88.5 \%)$ in this experiment.

TABLE 4

MERCURY AT 1300 ppb REMOVAL BY P. PUTIDA IN BIOREACTOR

\begin{tabular}{lcc}
\hline \hline Growth Parameter & Min & Max \\
\hline Specific growth rate, $\mu\left(\mathrm{hr}^{-1}\right)$ & 0.09 & - \\
OD & 0.40 & 2.57 \\
Exponential cell growth, & 0.01 & 0.27 \\
(ln OD/OD 0 & & \\
Hg Removal (\%) & 88.50 & - \\
\hline \hline
\end{tabular}

As the mercury concentration is further decreased over time, $P$. putida showed increasing growth behaviour and activity with higher cell density observed for the first 10 hours. Consequently, the OD and maximum exponential cell growth with 2.57 are obtained with initial growth of 0.40 . With the increasing cell density during the exponential phase, the specific growth rate, $\mu$ is $0.09 \mathrm{hr}^{-1}$.

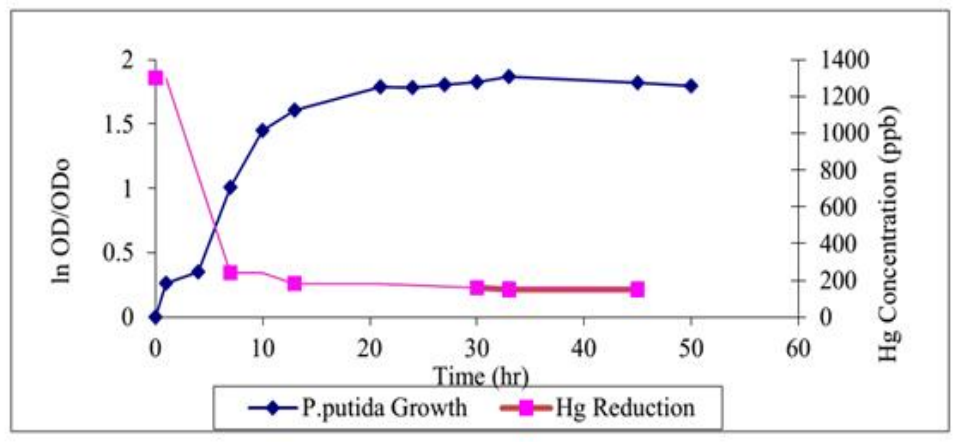

Fig. 2. Effect of mercury (1300 ppb) on the growth of $P$. putida

The effect of mercury removal at $3000 \mathrm{ppb}$ concentration on P. putida growth over time is shown in Table 5. Experiments are conducted at optimum operating conditions for less than 15 hours. Figure 3 shows the P. putida growth behaviour and the reduction of mercury concentration. Similarly as observed from previous study, there is no occurrence of lag phases, $P$. putida immediately grow exponentially after inoculation. However, mercury levels de- creased to almost $94 \%$ after less than 8 hours. With the decrease in mercury concentration, $P$. putida show an increasing growth and the maximum cell density is obtained after 2 hours of experiment. As a result, the maximum exponential cell growth is 1.88. Furthermore, it is found that after this period, cell growth is constant and slightly increased over time. 
TABLE 5

MERCURY AT 3000 ppb REMOVAL BY P. PUTIDA IN BIOREACTOR

\begin{tabular}{lcc}
\hline \hline Growth Parameter & Min & Max \\
\hline Specific growth rate, $\mu\left(\mathrm{hr}^{-1}\right)$ & 0.20 & - \\
OD & 0.24 & 3.00 \\
Exponential cell growth, & 0.06 & 1.88 \\
(ln OD/OD $)$ & & \\
Hg Removal (\%) & 94.00 & - \\
\hline \hline
\end{tabular}

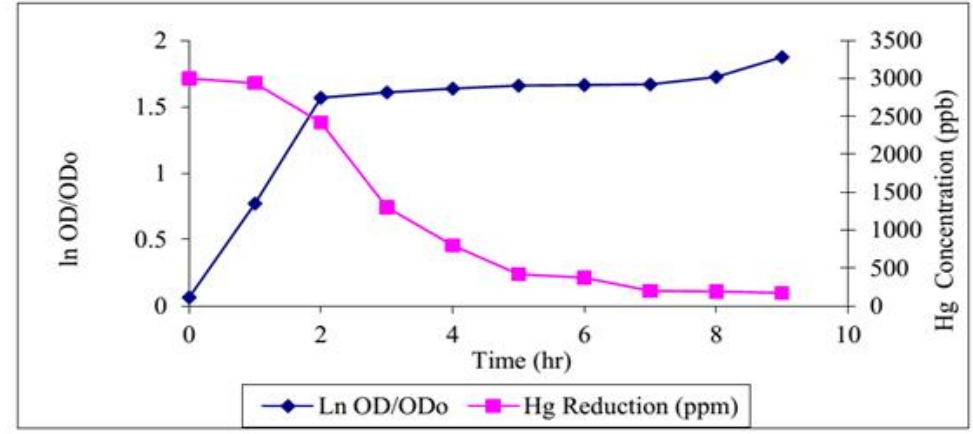

Fig. 3. Effect of mercury (3000 ppb) on the growth of P. putida

The specific growth rate, $\mu$ is $0.20 \mathrm{hr}^{-1}$, which is higher than the previous experiment. These parameters indicate slightly better performance at $88.46 \%$ compared to that obtained from the study carried out for $1300 \mathrm{ppb}$ mercury concentration but it was still considered good performance.

From both studies, the investigation obviously demonstrates that using higher mercury concentration at certain level will result in an improvement in the percentage of mercury removal by P. putida. Meanwhile, the percentage of mercury removal for mercury concentration of $10 \mathrm{ppm}$ is $80 \%$ as reported by Mortazavi [23]. Comparing with the results reported in the literature review, the performance at $88.6 \%$ mercury removal for $1300 \mathrm{ppb}$ and $94 \%$ removal for 3000 ppb are still acceptable. Meanwhile, Green-Ruiz [37] reported that for mercury concentration between $1000 \mathrm{ppb}$ and $2500 \mathrm{ppb}$, the mercury removal performance of bioremediation using Bacillus sp. was in the range of $78 \%$ to $88 \%$.

\section{CONCLUSION AND RECOMMENDATIONS}

The optimum operating conditions for the growth behaviour of $P$. putida in a shake flask were determined as acclimatization time of 24 hours, orbital shaker speed of $180 \mathrm{rpm}$, temperature of $37^{\circ} \mathrm{C}, \mathrm{pH} \mathrm{7}$, and nutrient con centration of $8 \mathrm{~g} / \mathrm{L}$. In the case of removal at low concentration mercury from the model wastewater, by applying the optimum operating conditions in the shake flask, it is found that the efficiency of mercury removal is $99 \%$ for $1.00 \mathrm{ppb}$ of mercury concentration, $99.8 \%$ for $6 \mathrm{ppb}$, and $98.6 \%$ for $19.00 \mathrm{ppb}$. The effect of $1000 \mathrm{ppb}$ mercury concentration is observed and the parameters obtained are as follows: $\mathrm{OD}_{\max }=0.89$; exponential growth $=1.90$ and specific growth rate, $\mu=0.700 \mathrm{hr}^{-1}$. The percentage of mercury removal is $92 \%$ for 1 hour and $98 \%$ for 28 hours.

For experiment using 2L bioreactor, the same optimum conditions were applied as shake flask which is acclimatization time of 24 hours, temperature of $37^{\circ} \mathrm{C}, \mathrm{pH} 7$, and nutrient concentration of $8 \mathrm{~g} / \mathrm{L}$. The optimum agitator speed is $180 \mathrm{rpm}$ and aeration time is $0.50 \mathrm{vvm}$. These operating conditions were applied for $1300 \mathrm{ppb}$ and $3000 \mathrm{ppb}$ mercury concentrations. The removal efficiency for 1300 $\mathrm{ppb}$ is $88.5 \%$ and $94.0 \%$ for $3000 \mathrm{ppb}$. The removal of mercury is successful by using mercury-resistant bacteria, $P$. putida.

This study offers an efficient way to reduce mercury contaminant in polluted wastewater. The method of study can be applied at pilot scale and also can be expanded to industry plants for their wastewater treatment. 


\section{REFERENCES}

[1] B. Braune, D. Muir, B. De March, M. Gamberg, K. Poole, R. Currie, M. Evans, S. Grundye, C. Heberta, R. Johnstoneh, K. Kiddb, B. Koenigi, L. Lockhartb, H. Marshallj... and L. Shutta "Spatial and temporal trends of contaminants in Canadian Arctic freshwater and terrestrial ecosystems: A review," Science of the Total Environment, vol. 230, no. 1, pp. 145-207, 1999.

DOI: $10.1016 / \mathrm{s} 0048-9697(99) 00038-8$

[2] D. Muir, B. Braune, B. De March, R. Norstrom, R. Wagemann, L. Lockhart, B. Hargrave, D. Bright, R. Addison, J. Payneg and K. Reimer, "Spatial and temporal trends and effects of contaminants in the Canadian Arctic marine ecosystem: A review," Science of the Total Environment, vol. 230, no. 1, pp. 83-144, 1999.

DOI: $10.1016 / \mathrm{s} 0048-9697(99) 00037-6$

[3] J. S. Chang, Y. P. Chao and W. S. Law, "Repeated fed-batch operations for microbial detoxification of mercury using wild-type and recombinant mercury-resistant bacteria," Journal of Biotechnology, vol. 64, no. 2, pp. 219-230, 1998 . DOI: 10.1016/s0168-1656(98)00112-6

[4] D. M. Manohar, K. A. Krishnan and T. S. Anirudhan, "Removal of mercury (II) from aqueous solutions and chlor-alkali industry wastewater using 2-mercaptobenzimidazole-clay," Water Research, vol. 36, no. 6, pp. 1609-1619, 2002.

DOI: $10.1016 / \mathrm{s} 0043-1354(01) 00362-1$

[5] A. Carpi, "The toxicology of mercury," Ph.D. dissertation, The City University of New York, New York: NY, 2001.

[6] W. Jeong, M. Kim, J. Park and J. H. Roh, "Relation between air pollutants emissions and BESS capacity operated for maximizing customer's profit," Journal of Applied and Physical Sciences, vol. 2, no. 2. pp. 54-64, 2016.

DOI: $10.20474 /$ japs-2.2.5

[7] D. R. Lovley and J. D. Coates, "Bioremediation of metal contamination," Current Opinion in Biotechnology, vol. 8, no. 3, pp. 285-289, 1997.

[8] F. Hayeeye, J. Yu, M. Sattar, W. Chinpa and O. Sirichote, "Adsorption of lead (ii) ions from aqueous solutions by gelatin/activated carbon composite bead form," International Journal of Applied and Physical Sciences, vol. 1, no. 2, pp. 32-35. 2015. DOI: 10.20469/ijaps.50002-2

[9] Y. Zeroual, A. Moutaouakkil and M. Blaghen, "Volatilization of mercury by immobilized bacteria (Klebsiella pneumoniae) in different support by using fluidized bed bioreactor," Current Microbiology, vol. 43, no. 5, pp. 322-327, 2001. DOI: $10.1007 / \mathrm{s} 002840010310$

[10] A. Malakahmad, A. Hasani, M. Eisakhani and M. H. Isa, "Sequencing Batch Reacto (SBR) for remival of $\mathrm{Hg}^{2+}$ and $\mathrm{Cd}^{2+}$ from synthetic petrochemical factory wastewater," Journal of Hazardous Materials, vol. 191, no. 1-3, pp. 118-125, 2011. DOI: 10.1016/j.jhazmat.2011.04.045

[11] K. Vijayaraghavan and Y. S. Yun, "Bacterial biosorbents and biosorption," Biotechnology Advances, vol. 26, no. 3, pp. 266-291, 2008.

DOI: $10.1016 /$ j.biotechadv.2008.02.002

[12] N. Sağlam, R. Say, A. Denizli, S. Patır and M. Y. Arıca, "Biosorption of inorganic mercury and alkylmercury species on to Phanerochaete chrysosporium mycelium," Process Biochemistry, vol. 34, no. 6, pp. 725-730, 1999. DOI: $10.1016 / \mathrm{s} 0032-9592(98) 00148-4$

[13] A. Demirbas, "Heavy metal adsorption onto agro-based waste materials: A review," Journal of Hazardous Materials, vol. 157, no. 2, pp. 220-229, 2008.

DOI: $10.1016 /$ j.jhazmat.2008.01.024

[14] A. Panrare, T. Tondee and P. Sohsalam, "Effect of plant density in constructed wetland on domestic wastewater treating efficiency" International Journal of Applied and Physical Sciences, vol. 2, no. 1, pp. 7-12, 2016.

DOI: $10.20469 /$ ijaps.2.50002-1

[15] A. Fakhru'l-Razi, A. Pendashteh, L. C. Abdullah, D. R. A. Biak, S. S. Madaeni and Z. Z. Abidin, Review of technologies for oil and gas produced water treatment," Journal of Hazardous Materials, vol. 170, no. 2, pp. 530-551, 2009.

[16] K. Nakamura, T. Fujisaki and H. Tamashiro, "Characteristics of Hg-resistant bacteria isolated from Minamata Bay sediment," Environmental Research, vol. 40, no. 1, pp. 58-67, 1986.

DOI: $10.1016 / \mathrm{s} 0013-9351(86) 80081-0$

[17] T. Stepheson, S. J. Judd, B. Jefferson and K. Brondle, "Membrane bioreactor for wastewater treatment," London, UK: IWA Publishing, 2000.

[18] G. Bitton, "Wastewater microbiology," Florida, FL: John Wiley \& Sons, 2005.

[19] P. Roya, R. Hadi, A. Hossein and M. Vahedian, "Survey of wastewater stabilization pond potential in meeting environmental standards," International Journal of Applied and Physical Sciences, vol. 1, no. 1, pp. 19-21, 2015. DOI: 10.20469/ijaps.50003 
[20] I. Wagner-Döbler, H. Lünsdorf, T. Lübbehüsen, H. F. Von Canstein and Y. Li, "Structure and species composition of mercury-reducing biofilms," Applied and Environmental Microbiology, vol. 66, no. 10, pp. 4559-4563, 2000. DOI: $10.1128 / \mathrm{aem} .66 .10 .4559-4563.2000$

[21] A. S. Hassan, C. A. Okuofu and J. K. Balogun, "The use of Biological Index of Pollution (BIP) in assessing quality of rural water sources in Zaria, Nigeria," Science World Journal, vol. 3, no. 2, pp. 101-105, 2008.

DOI: $10.4314 /$ swj.v3i2.51803

[22] H. Hussein, S, Farag, K. Kandil and H. Moawad, "Tolerance and uptake of heavy metals by Pseudomonads," Process Biochemistry, vol. 40, no. 2, pp. 955-961, 2005. DOI: $10.1016 /$ j.procbio.2004.04.001

[23] S. Mortazavi, A. Rezaee, A. Khavanin, S. Varmazyar and M. Jafarzadeh, "Removal of mercuric chloride by a mercury resistant Pseudomonas putida strain," Journal of Biological Sciences, vol. 5, no. 3, pp. 269-273, 2005.

DOI: $10.3923 /$ jbs.2005.269.273

[24] P. Li, X. B. Feng, G. L. Qiu, L. H. Shang and Z. G. Li, "Mercury pollution in Asia: A review of the contaminated sites," Journal of Hazardous Materials, vol. 168, no. 2, pp. 591-601, 2009.

DOI: $10.1016 /$ j.jhazmat.2009.03.031

[25] S. M. Wilhelm and N. Bloom, "Mercury in petroleum," Fuel Processing Technology, vol. 63, no. 1, pp. 1-27, 2000. DOI: $10.1016 / \mathrm{s} 0378-3820(99) 00068-5$

[26] M. Rebhun and N. Galil, "Technological strategies for protecting and improving the biological treatment of wastewater from a petrochemical complex," Water Science and Technology, vol. 29, no. 9, pp. 133-141, 1994.

[27] R. Eisler, "Mercury hazards to living organisms," Boca Raton, FL: CRC Press, Taylor \& Francis Group, 2006.

[28] M.S. Holtze, P. Nielsen, F. Ekelund, L. D. Rasmussen and K. Johnsen, "Mercury affects the distribution of culturable species of Pseudomonas in soil," Applied Soil Ecology, vol. 31, no. 3, pp. 228-238, 2006.
DOI: $10.1016 /$ j.apsoil.2005.05.004

[29] P. M. Dagegett and F. P. Simon, "Method of culturing freeze-dried microorganisms," 1987 [Online]. Available from: goo.gl/4TxPfz

[30] P. F. Standbury A. Whitaker and S. J. Hall, "Principles of fermentation techynology," Oxford, UK: Butterworth Heinemann, 1984.

[31] K. S. Sheikh, "Kinetics of 2, 4, 6-trinitrotoluene reduction by Pseudomonas," MSc. thesis, College of Engineering and Technology, Ohio University, Athens, OH, 2006.

[32] M. L. Shuler and F. Kargi, "Bioprocess engineering," Upper Saddle River, NJ: Prentice Hall PTR, 2002.

[33] C. J. Whitten and D. L. Bull, "Comparative toxicity, absorption, and metabolism of chlorpyrifos and its dimethyl homologue in methyl parathion-resistant andsusceptible tobacco budworms," Pesticide Biochemistry and Physiology, vol. 4, no. 3, pp. 266-274, 1974.

DOI: $10.1016 / 0048-3575(74) 90110-2$

[34] S. Singh, S. H. Kang, A. Mulchandani and W. Chen, "Bioremediation: Environmental clean-up through pathway engineering," Current Opinion in Biotechnology, vol. 19, no. 5, pp. 437-444, 2008.

DOI: $10.1016 /$ j.copbio.2008.07.012

[35] J. R. Lloyd D. R. Lovley, "Microbial detoxification of metals and radionuclides," Current Opinion in Biotechnology, vol. 12, no. 3, pp. 248-253, 2001.

DOI: $10.1016 / \mathrm{s} 0958-1669(00) 00207-\mathrm{x}$

[36] Environmental Quality Act (EQA), "Act 1272011 regulation, rules and orders," 1974 [Online].

Available from: goo.gl/y2RV6s

[37] C. Green-Ruiz, "Mercury (II) removal from aqueous solutions by nonviable Bacillus sp. from a tropical estuary," Bioresource Technology, vol. 97, no. 15, pp. 1907-1911, 2006. DOI: 10.1016/j.biortech.2005.08.014 